\title{
ICT and the Quality of Teaching: Some Hungarian Results of the OECD ICT Project
}

\author{
Andrea Kárpáti \\ UNESCO Centre for ICT in Education, Faculty of Sciences, Eötvös University, Budapest, \\ Hungary,karpatian@axelero.hu
}

\begin{abstract}
The educational research institute of OECD, CERI, commissioned an extensive study to investigate if and how ICT resulted in changes in the quality of learning. Between 1999 and 2002, a network of National Research Experts was set up who co-ordinate research in their countries and discuss the centrally developed tests, questionnaires and study outlines that were intended to capture similarities and differences of educational ICT policy in the countries concerned.
\end{abstract}

The primary goal of the studies reported here was to understand how ICT can relate to educational innovation. The present paper discusses results related to teacher competence, performance and motivation in the use of ICT in the 'model schools' of Hungary that proved to be especially effective in ICT use.

Diffusion process. Who were the early/late adopters of both the innovation and ICT? What incentives existed for adoption? Which organisational structures or processes were particularly important facilitators of change or barriers to it?

Role of leadership. Who directed the innovation? Did the role or manner of leadership change over the adoption period?

Importance of staff training: methods of achieving staff competence in using ICT and integrating it into the curriculum.

\section{INTRODUCTION}

Information and communication technologies-related educational investments are among the highest for all European countries. In the first phase of investment, between 1996-98, in Hungary, as everywhere else in Europe, most government funds were allocated to hardware and Internet connectivity. All around the world schools were supplied with tens of

The original version of this chapter was revised: The copyright line was incorrect. This has been corrected. The Erratum to this chapter is available at DOI: 10.1007/978-0-387-35701-0_35 
thousands of computers, and Internet connections were provided before substantial research on their functions and use had been conducted. The second phase, therefore, focused on content: development of educational software, quality assurance and promotion/evaluation of public-private partnership (OECD, 2001). The educational research institute of OECD, CERI, commissioned an extensive study to investigate if and how ICT resulted in changes in the quality of learning. The research project entitled 'ICT and the Quality of Learning' involved 23 member and allied countries.

The three sub-themes of the project were: Topic 1, 'Software Quality Issues', a series of national surveys that provided information on educational software development, quality assurance and monitoring of school use; Topic 2, 'Public-Private Partnership', which yielded an international collection of case studies of co-operation between industry and education, discussing and documenting a variety of internationally relevant, good models of encouraging, developing and maintaining such partnerships; and Topic 3, 'Experimental Studies', the Hungarian results of which will be discussed in detail in this paper, which investigated two main areas. National research teams conducted ethnographic surveys on the functioning of schools that incorporated ICT in education, internal and external communication and management. The other area was the study of ICT competencies in the framework of a 'quasi-experimental study' to test the development of computer skills, learning to learn skills and ICT-related attitudes of 17-year-old students who were taught with the help of new technology within the school year of 2000-2001 (Venezky \& Davis, 2001).

As part of Experimental Studies, there were school-based case studies that evaluated the functioning of schools incorporating ICT in their education, internal and external communication and management. Altogether 91 cases were documented in 23 countries to verify five pairs of hypotheses through 3-6 school studies per country The anthropological/qualitative approach included structured interviews, observation of teaching and extracurricular activities, and analysis of students' ICT-related work. Schools were revisited after 6, 12 and 18 months to see how educational change due to the introduction of ICT culture had occurred. The primary goal of the research reported here was to understand how ICT can relate to educational innovation. When making huge investments in computers and educational software, Hungarian educational policy makers were convinced, just like almost every other participant in the OECD study, that reforms would naturally follow. After the first phase of the computerisation campaign, 1990-98, statements about the effects of ICT became more modest, emphasising the importance of good practice and the leading roles of about $15 \%$ of secondary and $3-4 \%$ of primary schools that excelled in ICT 
policy and practice. As the OECD research project focused on cutting-edge institutions, we hoped to obtain results to be used in the second, more difficult phase of ICT-related reforms.

Data collection was carried out employing both qualitative and quantitative methods: interviews with teachers, administrators, students, parents, and technology specialists, on site observations of school life production of video films and photographs of spaces equipped with computers and related activities, analysis of digital products of students and teachers, survey of teacher ICT practices in class and in back office hours, analysis of public e-mail logs and interviews with knowledgeable people outside of the school: inspectors, principals of feeder and feed-to schools, business partners, community members, individual sponsors etc.

The Hungarian sample of ICT pioneers comprised two primary and four secondary schools, selected on the basis of successful involvement in at least two major national educational computing projects and providing evidence of regular ICT use in teaching and learning as well as communication and management. School 1 was an alternative secondary school of economics in Budapest - the first private secondary educational institution established after World War II in the country, in 1988. As a flexible and innovationoriented institution, it readily embraced the educational potential of the computer and tailored its functions and software options to the needs of a business-oriented institution cherishing humanistic values. With individual study programmes for every student, mixed-age student groups and a publishing house for textbooks written by the staff, this school was a paradigm example of ongoing reform. In contrast, School 2, another educational frontrunner - the first bilingual (English and Hungarian language) secondary grammar school in Budapest - safeguarded traditional values and study forms. A large and well-funded institution housed in a prize-winning, modern school building, it showed how tradition and innovation can be harmonised through ICT. School 3 was totally different from both: a modestly equipped primary school about 30 kilometres north of Budapest, in a village of small landowners that excelled in one respect 'only' - highly trained staff, totally devoted to ICT. This school acted as a catalyst for computer culture in the whole settlement where parents could learn about ICT only from their children. School 4, another primary school from a wellto-do town in southern Hungary, boasted a relatively good infrastructure and constant parental support in computer matters. School 5, a secondary vocational and grammar school in a middle-sized, unemployment-stricken town an hour's drive from the capital, was selected because of its excellent work in establishing a knowledge centre in its library and offering training in the most up-to-date ICT-related vocations. School 6, another secondary 
vocational school, was situated in one of the most affluent county seats and enjoyed the support of an interested and knowledgeable local government and parent community. Cutting-edge technology, a wide range of foreign connections and good management all contributed to making this school an ideal candidate for the study of best practice.

From the five investigated in the research project (discussed in detail in Venezky \& Kárpáti, in press), the following two problems will be summarised in the paper, based on Hungarian data: the diffusion process of ICT culture, and the role of school leadership in using ICT for more effective teaching, learning and communication. Both are related to the role of the teacher in the successful integration of ICT technologies. In a country with modest resources and traditionally good mathematicians and computer scientists, the human capital is the most important asset any reform can rely on. Our results show that Hungarian teachers are in fact the key players in the ICT in education game.

\section{DIFFUSION PROCESS OF ICT IN EDUCATION}

In 2002 about 2.1 million Hungarians $-25 \%$ of the adult population possess a computer. The number of Internet subscribers has quadrupled within the last two years. In a country of about 10 million inhabitants this is still not satisfactory but represents a $40 \%$ increase as of $2001.85 \%$ of Hungarian Internet users have access at school or work. The largest age group (an estimated $50 \%$ of the total) among regular computer users, as in other countries, is the young: students and professionals between 18-29 years of age. The digital divide in Hungary is age-related, similarly to the gap separating the yuppie generation from their parents. Only $6 \%$ of those above 60 years of age were sufficiently courageous to try out and use computer technology. (Considering the percentage of teachers employed near and above pension age -62 years for women and 65 years for men - about $30 \%$ of teachers belong to this 'ICT - no, thanks' subculture.) Another divide is of a geographical nature: a little less than $50 \%$ of Internet surfers live in the capital, Budapest and a further $30 \%$ are the inhabitants of a county seat or big country town. These data place Hungary in the middle of European computer user rates.

In Hungarian public education, Information Technology as a discipline dates back to the 1970s. From the 1980 s, a shift is observable from a technology-centred towards a teaching/learning-centred approach (Kárpáti, in press; Turcsányi-Szabó \& Ambruszter, in press). Today, it is a compulsory discipline for grades 6-8 (student ages 12-14) in the primary and 6-grade secondary school and grade 9 (age 15) in the 4-grade secondary 
school. The content of ICT studies has shifted from subject-specific studies towards a cross-curricular approach - teachers of all disciplines are trained and encouraged to teach ICT skills related to their area of studies. At present, training of intelligent users seems to be at the focus of curricula (Körösné Mikis, 2002).

When we examined diffusion patterns of ICT culture in the OECD study, we wanted to find out if the diffusion pattern by Rogers (1995) was applicable in countries with a wide variety of cultures and financial means. The starting point for Rogers is to view schools as social systems composed of individuals with varying degrees of openness to technological innovations. He divides potential adopters into five categories, based upon socio-economic status, communication behaviours, and personality values. This diffusion pattern includes a small group of Innovators (the first $2.5 \%$ to adopt), a larger group of Early Adopters (the next $13.5 \%$ to adopt), an even larger group of Early Majority (the next $34 \%$ ), with the rest distributed among the remainder groups of Late Adopters and Laggards. In the OECD study, national researcher teams did not provide such quantitative definitions, only general trends described in the model were verified. Traditional diffusion patterns held in almost every school in the OECD sample - Hungary included.

In School 1, the early adopters included junior staff members who came fresh from college with reasonably up-to-date ICT skills. As transparency of operations and democratic forms of communication between leader and staff, teachers and students were facilitated by computer culture, its importance for flexible learning management in this school with individual study paths was soon declared as a necessity. Late adopters were few: mostly teachers of arts who feared their discipline would suffer if the 'human touch' was even partially replaced by touching buttons. In School 2, bilingual educators soon realised the Internet was an invaluable asset for authentic language learning. Here, Early Adopters included English teachers quickly followed by science and the fine arts educators. The latter, an elderly lady who learnt computer-assisted design at the age of 65 , became a national role model for media oriented art teachers. However, most older teachers decided to wait. Laggards were those who thought pension age was too close to bother about learning new, seemingly complicated skills.

Schools 3 and 4, the two primary institutions showed that the ideal age for successful teaching in a computer-supported environment was between 35 and 45. Contrary to our expectations, best educational users - those who were most competent in the use of ICT for teaching and self-guided studies turned out to be middle-aged professionals who were experienced in the practice of teaching and knew how to harmonise new methods with 
traditional ones. Young teachers were often afraid of entering 'the road less travelled' and were too preoccupied with the chores of teaching and the intricate process of fitting into a school staff (cf. Fehér, 2000). Similar findings were reported in another European study on school culture that monitored average institutions. (For Hungarian results, see Kárpáti, 2001.)

In Schools 3 and 5, the head teacher dictated the pace of changes - more about this in the following section on the role of leadership. The staff followed the lead more or less enthusiastically because the mission statements of both schools, and all financial and other management decisions that followed, clearly indicated that you either adopt ICT in your teaching practice or leave. There was an immense pressure from parents who demanded education in marketable jobs for their children that made Schools 5 and 6 among the first in the country to adopt ICT-supported vocational training programmes.

Interestingly, gender was not an issue. As the majority of primary and more than half of secondary school teachers are women, ICT pioneers had an equal number of male and female teachers in the Early Majority category although among Early Adopters, the number of male teachers was higher. Being an ICT teacher is also a suitable and attractive profession for women perhaps because male ICT specialists will rarely choose the teaching profession as they have other, more lucrative job offers that major family providers (in Hungary, these are the men) cannot refuse. In Schools 3, 4, 5 and 6, we met competent female systems operators who most often served as ICT teachers as well, and who could in turn serve as role models for girls, having in fact made them interested in computer culture.

Incentives for adoption included free courses in educational computing to learn a fashionable skill turned out to be very motivating. 'Computers for teachers' campaigns by the educational government offered cheap PCs for home use for those who demonstrated ICT skills in teaching. The most important facilitators of change were systems operators - in fact, their role turned out to be crucial. Three of our schools - 1, 2, and 6 - employed a fulltime support person. The others managed to have only part time help but intended to exchange this arrangement for at least one full time position.

In the late seventies, teacher training programmes and in-service training courses were introduced in large numbers to satisfy the accelerating need for ICT educators. Already at this phase, an important objective was formulated but, unfortunately, not realised until about two decades later: to train teachers of different disciplines in basic programming and/or educational software use to enable them to use computers in their preparation and daily teaching practice. Thus, teachers of disciplines other than ICT had to rely on their own initiative at the start - a fact that made diffusion slower than expected. Today, a wide range of in-service training programmes facilitates 
computer-supported learning and, as a result, the spread of new tools and methods has accelerated. In all of our selected, frontrunner schools, at least $60 \%$ of staff has a certificate in educational computing. In School 3, the smallest and poorest of all, 100\% of staff has obtained a diploma in ICT education and thus managed to overcome deficiencies of infrastructure and become one of the best performers among primary schools in this area. Diffusion, we found, is more closely related to teacher training and motivation than to available material resources and equipment - a result that gives hope to less affluent countries showing the predominant role of human potential in ICT-related educational reforms.

The location of schools turned out to be another important factor influencing use patterns and teacher roles in educational computing. Most primary teachers living in villages expressed their discontent with ICT training, tools and infrastructure - they seem to be more critical than their counterparts in towns and cities with similar equipment. Apparently, the Internet as a source of information and communication has a geographical value in education. It means entirely different things for a teacher living in close proximity to libraries, museums, universities and community centres than for those who have to make up for the lack of all these through skilfully using the Net. Access to traditional teaching resources and in-service training is also difficult for this group of educators so they are ready to use ICT to make their own up-to-date teaching aids using a scanner and desktop publisher to construct learning materials from the text and image databanks on the web.

However while its diffusion pattern is similar to those of previous educational innovations, (overhead projector, educational television, pen and pencil tests, project-based teaching, portfolio assessment), computer technology still functions differently as it is extremely flexible and thus targets all areas of teaching and learning, management and assessment.

\section{ROLE OF LEADERSHIP}

The most intensive phase of hardware development in Hungary occurred between 1995 and 1997, when the World Bank and PHARE launched their big ICT projects in the country (cf. Turcsányi-Szabó \& Ambruszter, in press). Between 1997-1999, however, the Ministry of Education initiated a massive computerisation movement. 3 billion Hungarian forints (HUF) (approx. 500,000 USD) was allocated, to connect all secondary schools (about 700 in number), $30 \%$ of primary schools (400 in all), and one educational institute per county ( 22 in all), to the Internet. By the end of 
1999, this ambitious plan was accomplished. The role of school leadership in applying for grants and facilitating the work of ICT-oriented teachers has been crucial from the start. As most resources were and still are allocated on an application basis, head teachers are key elements of innovation.

At present, Hungarian schools are moderately equipped - and, as our results show, the dedication of management and the level of infrastructure are closely related. A good example of this is School 2, that had been in the front line of all innovation and research efforts related to ICT and made an optimal use of computer culture in all areas of school life. It had an entrance registration system with chip cards, an intranet was the basic source of communication for the large staff, the Internet was regularly used for teaching. There were also high quality teacher pages and alumni even kept coming back to design and run the student pages and news network.

But what if the head teacher prefers other areas of innovation? In School 5 , one of the flagships of computerisation at the time of our survey, there was a change in leadership that resulted in a preference for other educational areas. The school still enjoys a relatively up-to-date infrastructure but staff dedication and innovative projects are on the decrease. From cutting edge to average in ICT - it took only two years for this school to completely change orientation. Decrease in performance was even quicker in School 3. After our survey, the local educational authority decided not to prolong the contract of the head teacher who turned out to have been instrumental in ICT-supported reforms. The school excelled in practically every learning criterion and attracted groups of visitors interested in village ICT culture from all over the country. Thus, the forced change in leadership could not have indicated discontent with results, but a wish of local authorities to change directions of development. The head teacher left together with about 15 loyal staff members (70\%) and today the school has practically abandoned all features that qualified them as outstanding in ICT. As a consequence, village children have lost a chance to obtain free training in key labour market skills.

When leadership does not prefer ICT, interested teachers must turn to peer support (Leask \& Younie, 1999). The Hungarian Schoolnet was established in 1998 to provide educational and technical help for connected schools. Members of our Schoolnet receive free, 24-hour Internet connection (mostly ISDN), a computer laboratory with up to $20 \mathrm{PCs}$ and a server, a software and printed manual package called Internet Starter's Kit. The Schoolnet Office employs a large group of part-time subject specialists who create a weekly updated, authentic content-rich and therefore increasingly popular web site: http://www.sulinet.hu. It is a problem that the Hungarian Schoolnet is mainly for secondary schools, so most of their materials are not directly useful for primary school teachers. In Schools 3 and 4, therefore, 
teachers must engage in adaptation or even in the development of software a time-consuming innovation that would have been impossible without firm leadership support (Halász, 1998, 1999).

School leadership in Hungary is at present not in the position to totally disregard ICT-related innovation. Obligatory data provision is Internet-based and so are information resources vital for the day-to-day functioning of educational institutions. Through central measures, the Hungarian government managed to make the use of ICT practically compulsory for all schools in the country - at least for management purposes. The Central Educational Information Database (KIFIR) supplies information on educational institutions in the country and is an essential resource for teachers who are obliged to offer study and career counselling to students and parents. The KIRSTAT system is our Central Educational Statistics Database that requires the submission of digital data regularly from all schools. Head teachers in our survey first found these requirements difficult to meet but soon reported that computerised data processing made their work a lot easier. Similar findings were disclosed from other national studies (e.g. Csákó, 1989, 1999; OEAS-Europe Survey, 2000).

The role of leadership in ICT-related innovations was generally considered highly important in the OECD survey. The integration of ICT into instruction and learning was found to depend mostly upon staff competence with head teachers playing an instrumental role. As they decide on the allocation of finances and co-ordinate most grant applications, providing means for ICT-generated reform is clearly in their hands. Teachers are trained to choose and use ICT applications suitable for their discipline in every country and thus may facilitate and, through their demands for new tools and teaching aids, encourage the work of leadership. We found that the best and most innovative teachers are likely to be good ICT users as well. Influential figures in their schools, they often act as a body of consultants for their head teacher and thus support the innovation process that naturally follows the introduction of ICT. Similar relationships were also reported in other international studies (Passey \& Samways, 1997).

\section{CONCLUSION}

Both leadership and good teachers, however, have to be convinced that expensive infrastructure that requires constant maintenance will actually result in better teaching and more effective learning. In-service training courses conducted at well-equipped college campuses or laboratories of training firms were found less effective as teachers were returning to their 
schools and being faced with problems of a different, inferior infrastructure, and so could not employ freshly gained knowledge. Therefore the Hungarian research team invited participating schools to join on-site, school-based training courses and teaching experiments during the OECD ICT project: Learning communities for teachers and university staff members. This proved to be highly effective in facilitating improvement and gained positive recognition from school leadership. Teaching experiments for six disciplines, which lasted for two years, were expanded to involve 90 schools. A series of manuals, videotapes, demo CDs, test software as well as pre- and in-service training modules for teacher training programmes was elaborated. These are now being used as propaganda materials for convincing hesitant head teachers about the benefits of ICT for education.

In Hungary the OECD/CERI research project, entitled 'ICT and the Quality of Learning' has been slightly altered in direction to emphasise the importance of dissemination of good practice in computer-generated reforms. The title of this paper indicates this endeavour and formulates our most important result: though ICT can be used for traditional, frontal delivery of knowledge, it opens new perspectives for modern educational paradigms and has an inherent motivating capacity for teachers and students alike. In this paper, the pattern of diffusion and the role of leadership in the diffusion process was outlined - in papers that follow, the importance of technology, teacher education and student competence will be evaluated and contrasting view about the effects of ICT-related reforms discussed (Venezky \& Kárpáti, in press).

\section{REFERENCES}

Csákó, M. (1989). Computers, Schooling and the School (Számitógép, Oktatásügy, Iskola). Unpublished research report (in Hungarian). Budapest: Institute for Social Studies (Társadalomtudományi Intézet).

Csákó, M. (1999). Teacher Attitudes towards ICT at School - with Special Regard on the Internet. (Pedagógus Attit_dök az Iskolai Informatikával szemben - különös tekintettel az Internetre.) Unpublished research report. Budapest: Institute for Social Studies (Társadalomtudományi Intézet).

Fehér, P. (2000). The Road Less Travelled: ICT Culture of Hungarian Village Schools. Presentation at the Ninth EARLI Conference, Friburg, Switzerland. Retrieved from http://www.mek.iif.hu/porta/szint/tarsad/pedagog/infoktat/road

Halász, G. (Ed.) (1998, 1999). Report on Hungarian Public Education. Budapest: National Institute for Public Education.

Kárpáti, A. (2000). ICT in Hungarian education: Who/What is inside the Trojan horse of education? International Journal of Educational Theory, Research and Practice, 2, 23-30.

Kárpáti, A. (2002). ICT Culture in Hungarian schools - Results of the OECD study from a central European perspective. In Proceedings of the IFIP SEC III Conference, Dortmund, University of Dortmund (CD-ROM publication). 
Kárpáti, A. (2001). Report of the Hungarian case studies of the EMILE Project (full English online version available at the project web site: www.emile.eu.org).

Kárpáti, A. (in press). ICT in Hungarian public education - An overview. Journal of Educational Multimedia and Hypermedia.

Körösné Mikis, M. (Ed.) (2002). ICT Across the Curriculum (Informatikai kereszttanterv). Budapest: Ministry of Education (Oktatási Minisztérium). In Hungarian.

Leask, M. \& Younie, S. (1999). Characteristics of effective on-line communities for teachers: Issues emerging from research.' In Proceedings of IIIrd Open Classroom Conference (pp. 192-197). Balatonfüred: EDEN (European Distance Education Network).

OECD (2001). Schooling for Tomorrow - Learning to Change: ICT in Schools. Paris: OECD.

OSEAS-Europe Survey: Education of Hungary (2000). Retrieved from http://www.ksh.hu/pls/ksh/docs/index_eng.html

Passey, D. \& Samways, B. (Ed.) (1997). Information Technology: Supporting Change Through teacher Education. London: Chapman and Hall, IFIP.

Rogers, E. M. (1995). Diffusion of Innovations. New York: Free Press.

Turcsányi-Szabó, M. \& Ambruszter, G. (in press). The past, present and future of ICT in education - the Hungarian image. International Journal of Continuing Engineering Education and Life-Long Learning.

Venezky, R. \& Davis, C. (2001). Quo Vademus? The Transformation of Schooling in a Networked World. Draft Executive Summary of the OECD Project, 'ICT and the Quality of Learning'. Paris: OECD.

Venezky, R. \& Kárpáti, A. (Eds) (in press). Case Studies on ICT and Educational Change Issues from the OECD Project ICT and the Quality of Learning. A special Issue of ECI (Education, Communication and Information). 